\title{
ANTIMICROBIAL PEPTIDES FROM MUSSEL MYTILUS GALLOPROVINCIALIS: THE MYTICINS
}

\author{
Beatriz Novoa $^{1}$, Amparo Estepa ${ }^{2}$, Antonio Figueras ${ }^{1}$ \\ ${ }^{1}$ Instituto de Investigaciones Marinas (IIM), CSIC, Vigo 36208, Spain. ${ }^{2}$ Department of \\ Biochemistry, Universidad Miguel Hernández, Elche (UMH), Alicante, Spain.
}

\begin{abstract}
Antimicrobial peptides (AMPs) have been found in different bivalve species but a remarkable abundance of these small peptides has been reported for the Mediterranean mussel, Mytillus galloprovincialis. In particular, the myticin $\mathrm{C}(\mathrm{Myt} \mathrm{C})$ is the most abundantly expressed gene in cDNA libraries and also in Next generation sequencing projects after immune stimulation. This AMP presents a high genetic variability but until now the mechanism to generate it is unknown. Myt $\mathrm{C}$ is mainly present in hemocytes and also in serum where it is constitutively found in proteomic studies. Also, Myt $\mathrm{C}$ modulates the immune system because its overexpression is able to alter the expression of other mussel immune-related genes. Our results indicate that Myt $\mathrm{C}$ has antibacterial, antiviral and chemotactic properties being active across species due to its strong antiviral activity against a fish rhabdovirus. All these results suggest that this molecule should be considered not only as an AMP but also as the first chemokine/cytokine-like molecule identified in bivalves and one of the few examples in all of the invertebrates.
\end{abstract}

\section{KEYWORDS}

Antimicrobial peptides; bivalves, Myticin, antiviral activity

Corresponding author: Tel.: +34 986214463; Fax: +34 986292762

E-mail address: beatriznovoa@iim.csic.es 